N. Kuzmenko, Doktor of Pedagogical Sciences, Professor of Pedagogy Department

Taras Shevchenko National University of Kyiv, Kyiv, Ukraine

G. Varvaretska, assistant

National University "Odessa maritime University", Odesa, Ukraine

\title{
THE HIGHER SCHOOL TEACHER'S IMAGE AS A COMPONENT OF PROFESSIONAL AND PEDAGOGICAL CULTURE
}

The article points out that the modern tendencies of education are the modernization of it's content, forms and methods, development and testing of new educational and psychological technologies, the emergence of new types of educational institutions. These changes, in turn, depend on require the constant work of the head of the educational institution over the image of their institution, their own image and the reputation of research and teaching staff. The article deals with the most important components without which the formation of a positive image of a high school teacher is not possible. It was revealed that one of the factors for creating a positive image of the future specialist is the educational environment of the higher education institution and, in particular, the influence of the teaching staff. The role of the teacher's image in the formation of students' professional and personal qualities was analyzed. The essence of the concept of pedagogical image, its formation and development, functions of image, structure of personal image are determined. These include, in particular, professional competence, universal values, moral standards, managerial culture and technology of self-presentation. The article provides examples of the influence of the teacher's appearance on the level of information assimilation by students. The connection between the components of the image and the components of the teacher's pedagogical skill of the institution of higher education was established, the interdependence of teacher's positive image and his or her humanistic orientation was determined. The ways of formation teacher's positive image and development of pedagogical skill are outlined. The types of public image are defined, kinetic and speech image are characterized. The article substantiates that the teacher's positive pedagogical image is able to promote the rise of the efficiency of pedagogical activity and is able to shape the style of social behavior of the high school teacher. Research on this problem and recent publications of domestic and foreign scientists are analyzed.

Keywords: professional and pedagogical culture, education manager, pedagogical image, image functions, components of the image, types of image, kinetic image, speech image, self-presentation.

удк 378

DOI: https://doi.org/10.17721/2415-3699.2020.12.07

А. Марушкевич, д-р пед. наук, проф. Київський національний університет імені Тараса Шевченка, Київ

\section{ЗАБЕЗПЕЧЕННЯ ЯКОСТІ ОСВІТИ В СУЧАСНОМУ ЗВО: АКТУАЛЬНІ ІДЕЇ}

Розглянуто актуальні ідеї щодо забезпечення якості освіти в закладах вищої освіти України; наголошено на їі суттєвих характеристиках $і$ важливості взаємоузгодження навчальних планів у вітчизняних $і$ зарубіжних 3ВО; обґрунтовано суть понять "якість освітньої діяльності" та "якість вищої освіти", "академічна спільнота", "університетська спільнота", "антикорупційна програма"; доведено значення взаємодії викладачів і студентів у процесі навчання.

Ключові слова: якість освітньої діяльності, якість вищої освіти, компетентності, університетська спільнота, академічна спільнота, викладачі, студенти.

Постановка проблеми. Україна, як незалежна суверенна держава, співпрацює з багатьма країнами світу у справі поліпшення своєї економічної, політичної, культурної складових забезпечення життєдіяльності народу. Важливою в цій співпраці є підтримка освітньої галузі, яка реформується й оновлюється шляхом налагодження зв'язків із закладами освіти далекого і близького зарубіжжя. Це спрямування потребує від ії̈ науково-педагогічної спільноти забезпечення оптимальних умов для індивідуального розвитку особистості, її духовного потенціалу. Відповідно, у Законах України "Про вищу освіту" (2014), "Про освіту" (2017) висуваються вимоги щодо формування у молоді здатності до комунікацій, професійних якостей і навичок, які сприятимуть у досягненні нею цілей та успіху в реалізації своїх можливостей на ринку праці. У зв'язку з цим в Україні здійснюється докорінна зміна підходів до забезпечення освіти, зокрема вищої, зумовлена орієнтацією суспільства на розвиток мобільної, здатної до змін в особистісних і культурних якостях відповідно до вимог часу людини. Це викликане змінами у суспільній свідомості, оціночному ставленні народу щодо фуннкціонування й розвитку освітньої сфери, її ролі у творенні нової, спрямованої на вдосконалення особистості системи надання освітніх послуг, зосередженої на підтримці саморозвитку особистості, виробленні в неї необхідних якостей для професійної діяльності. Суттєвими характеристиками вищої освіти в нинішніх умовах $€$ її динамічність та інтернаціональність. Спостерігається розширення доступу до навчання у ЗВО не лише громадян України, а й представників інших країн, їхня рівність щодо вступу. Особлива увага держави звернена на поліпшення якості вищої освіти, що суттєво впливає на забезпечення ринку праці висококваліфрікованими фрахівцями, спроможними протистояти викликам часу.
Мета публікації полягає в розгляді актуальних ідей щодо забезпечення якості вищої освіти в Україні з урахуванням вимог сучасного суспільства до навчання здобувачів вищої освіти у ЗВО.

Завдання публікації - розкрити актуальні ідеї забезпечення якості вищої освіти в Україні; обґрунтувати необхідність якісного навчання здобувачів вищої освіти для їхньої конкурентоздатності на ринку праці у прийдешньому.

Аналіз останніх досліджень і публікацій. Проблема забезпечення якості вищої освіти в Україні вивчається й аналізується представниками різних галузей наукового знання. Натепер опубліковано значна кількість наукових праць, у яких автори намагаються висвітлити проблеми та шляхи їхнього подолання в освітній галузі, аналізують запозичений світовий досвід навчання і виховання студентів, їхньої професійної підготовки й реалізації як самодостатніх фахівців на ринку праці. Ідеї забезпечення якості вищої освіти знаходимо у працях відомих українських учених В. Андрущенка, І. Беха, С. Домбровської, П. Клімової, К. Корсака, В. І. Лугового, Ж. Таланової та ін. Ними зацікавлена велика кількість молодих дослідників: аспірантів і докторантів. Розглядають ці питання в дипломних роботах випускники ЗВО. Із цього бачимо, що проблема $є$ актуальною й до кінця не вивченою.

Викладення основних положень. Європейський і світовий освітній простір орієнтується на таку складову характеристики якості функціонування ЗВО як мобільність його студентів, науково-педагогічних працівників, керівного складу. У цьому руслі професійна підготовка здобувачів вищої освіти включає взаємоузгодження навчальних планів, що сприяє адаптації студентів до умов навчання не лише у вітчизняних закладах вищої освіти, а і у відповідних 3ВО інших країн та уможливлює отримання подвійних дипломів. 
У зв'язку з важливістю такої взаємодії між вітчизняними й зарубіжними університетами посилюються вимоги до особистості науково-педагогічного працівника, його якостей, рівня компетентності. Успішність викладача в роботі з молоддю залежить від багатьох фракторів, серед яких - його авторитет, взаємодія із представниками університетської спільноти, правильна побудова взаємостосунків, уміння швидко орієнтуватися в будь-яких ситуаціях тощо. Особливої уваги потребує порозуміння і творча взаємодія зі студентами (врахування їхніх індивідуальних особливостей, встановлення довірливих і доброзичливих стосунків, розуміння проявів їхньої емоційно-вольової сфери, відчуття потреб, які з'являються, прогнозування наслідків своїх дій тощо).

Дотримуючись Закону України "Про вищу освіту" (2014) науково-педагогічні працівники мають забезпечувати якість освітньої діяльності, яка трактується в названому документі як "рівень організації освітнього процесу у вищому навчальному закладі, що відповідає стандартам вищої освіти, забезпечує здобуття особами якісної вищої освіти та сприяє створенню нових знань" [4, с. 3]. В аналізі В. А. Бугрова якість освітньої діяльності визначається як сукупність характеристик системи вищої освіти та її складових, що стосується здатності задовольняти встановлені й передбачені потреби окремої особи та суспільства [2].

Відповідно до Закону України "Про вищу освіту" усвідомлюємо, що поняття "якість вищої освіти" включає у свій зміст сукупність таких характеристик фахівця з вищою освітою як її професійна компетентність, здатність до подолання не лише проблем свого кар'єрного зростання, а й спроможність коригування, сприяння в розв'язанні суспільних негараздів. Суть поняття "якість вищої освіти" може підтверджуватись здатністю її здобувачів накопичувати знання, розвивати вміння самостійного навчання і творчого мислення, виробляти навички прийняття своєчасних науково обґрунтованих рішень, продукування нових ідей, виявляти схильність до конструктивної діяльності, володіти високим рівнем духовності й культури.

Якість вищої освіти була й залишається серед пріоритетних умов розвитку освітньої політики держави, на яку спрямована діяльність усіх без виключення 3ВО. Розглядаючи питання про важливу роль ЗВО у її фрормуванні звертаємо увагу на внутрішні характеристики якості ВО, виокремлюючи якість діяльності університетської спільноти, яка включає "професорсько-викладацький склад, адміністрацію Університету та його структурних підрозділів, наукових працівників, слухачів підготовчих відділень, студентів, аспірантів, докторантів, навчальнодопоміжний персонал, працівників адміністративно-господарської частини" [3, с. 2]. Від кожного її представника залежить ефективність управління освітнім процесом 3ВО, фрункціонування його організаційної структури, підготовка кадрового потенціалу, діяльність науково-педагогічного складу університету, ступінь зацікавленості студентів навчанням, рівень підготовки аспірантів і докторантів, стан науково-методичної роботи, ресурсного забезпечення підрозділів тощо.

Важливу роль у забезпеченні якості освіти відіграє академічна спільнота, тобто "всі члени університетської спільноти, які беруть участь в освітній і науковій діяльності Університету" [3, с. 2]. Увага академічної спільноти зосереджена на науковості змісту навчальних дисциплін, якості підручників, навчальних посібників та інших видань, педагогічній майстерності і творчості викладачів, врахуванні ними виважених підходів до навчання студентів з особливими потребами, використання сучасних засобів навчання, застосування новітніх технологій.
У нинішній час швидкого розвитку останніх важливого значення набуло втілення в освітній процес ЗВО нововведень, інновацій (італ. innovatione - новизна). Цьому сприяє усвідомлення адміністрацією закладу вищої освіти наукових засад процесу управління, аналітичної діяльності як його основного інструмента, нових технологій керування й оцінювання діяльності структурних підрозділів; систематичне накопичення бази даних про вітчизняні та зарубіжні освітні інновації; інтеграція в міжнародний освітній простір.

Натепер ефективність функціонування закладу вищої освіти здебільшого залежить від якості інформаційного забезпечення, яке наявне в ньому. Створенню такого забезпечення передує велика аналітична робота щодо визначення його змісту, обсягу джерельної бази, місця зберігання, способів використання тощо.

Управлінська практика вказує на необхідність системного наукового бачення керівництвом 3ВО динаміки розвитку, його зв'язку з соціально-економічним середовищем, конкурентоздатності як освітнього й наукового центру підготовки молодих кадрів, ринкового попиту на випускників і т. п.

Забезпечення якості вищої освіти розглядається як одна з найважливіших проблем сучасності на міжнародному рівні та здійснюється на основі принципів взаємодовіри, взаємоповаги. Важливим у цьому процесі $€$ науково-дослідницький аспект діяльності 3ВО, навчання здобувачів вищої освіти на основі найважливіших досягнень у галузі науки і практики, формування в них навичок критичного мислення.

В умовах сьогодення в закладах вищої освіти необхідно готувати фахівців, здатних працювати за умов частої змінюваності вимог до кадрів різних кваліфікацій на ринку праці i, при цьому, приймати неординарні рішення. Це спонукає викладачів до застосування під час навчання активних методів, усвідомлення ними необхідності переосмислення свого минулого досвіду з метою отримання високого результату роботи. До того ж, для успішного впровадження інновацій важливим $€$ врахування ставлення всього колективу науково-педагогічних працівників до цього процесу, наявність устаткованого на сучасному рівні аудиторного фонду, потрібних приладів, пристроїв, технічних засобів. Необхідною $є$ організація нових пошуків, відкриттів на основі здійснюваних досліджень за актуальними науковими темами. Втілення в освітній процес інновацій має певну послідовність, яка базується на виявленні інноваційних ідей, створенні розробок щодо їхнього впровадження, аналізі їх змісту науково-педагогічними працівниками, застосування у практичній діяльності, оцінювання якості застосування, вироблення рекомендацій щодо подальшого розповсюдження.

У Законі України "Про освіту" (2017) вказано: "викладацька діяльність - діяльність, яка спрямована на формування знань, інших компетентностей, світогляду, розвиток інтелектуальних і творчих здібностей, емоційновольових та/або фрізичних якостей здобувачів освіти (лекція, семінар, тренінг, курси, майстер-клас, вебінар), і яка провадиться педагогічним (науково-педагогічним) працівником, самозайнятою особою (крім осіб, яким така форма викладацької діяльності заборонена законом) або іншою фізичною особою на основі відповідного трудового або цивільно-правового договору" [5, с. 1]. Викладач сучасного ЗВО у своїх підходах до виконання професійних обов'язків має врахувати виклики сьогодення й пам'ятати: затребуваним $€$ той фахівець, у якого присутнє гнучке мислення, розвинута здатність приймати швидкі рішення, знаходити необхідну інформацію, налагоджувати контакти, проводити "нестандартні" заняття 
тощо. Він має тісно співпрацювати з керівництвом конкретного підрозділу, впливаючи тим самим на ефективність діяльності 3ВО, його авторитет в Україні та світі.

Важливе значення для сучасного викладача має поліпшення його обізнаності у сфері своєї діяльності шляхом підвищення кваліфрікації, самопідготовки, наявність персонального кабінету, із якого він при потребі може проводити заняття, здійснювати дистанційне навчання, обмінюватися інфрормацією як зі студентами, так і з колегами. Персональний кабінет уможливлює викладачу доступ до розкладу занять, перегляду навчальних планів, електронних журналів, автоматизованих бібліотек, електронного репозиторію тощо. Відповідно, персональні кабінети можуть використовувати і студенти. Це допоможе їхньому контактуванню з викладачами, перегляду необхідної інформації, ознайомленню з ресурсами бібліотек, проходженню тестування, дистанційному навчанню і т. п.

Молодь, під керівництвом висококваліфікованих наставників, навчаючись у закладі вищої освіти, оволодіває необхідними компетентностями, професійно-особистісними якостями, які $€$ визначальними у її подальшій життєдіяльності.

Як і давніше, натепер основним видом навчального заняття є лекція, на якій викладач доносить студентам великий обсяг інформації. Проте вимоги з їхнього боку до неї посилились, її класичний варіант не завжди задовольняє молодь. Усе частіше студенти схвалюють мультимедійні лекції, тренінг-лекції, лекції-дискусії, які активізують їхню активність і спонукають до співпраці. Їхня організація потребує спеціальних аудиторій, оснащених сучасними засобами навчання: комп'ютерами, проєкторами, екранами, доступом до інтернету тощо. Мультимедійні лекції організовуються завдяки творчості та педагогічній майстерності викладачів. До їхньої підготовки залучаються студенти, які спроможні створювати мультимедійні презентації і, таким чином. підвищувати рівень своїх знань.

Користуються популярністю організовані науково-педагогічними працівниками інтерактивні дискусії. Популярними для спілкування викладачів і студентів стали Інтернет-форуми, листування електронною поштою, контактування в "чатах"... Усе це потребує ретельного планування, дотримання етичних норм спілкування, обізнаності зі спеціальними комп'ютерними програмами. Організація інтернет-форумів є трудомісткою, оскільки у них передбачається індивідуальна участь студентів. Кожен із них може ознайомитися зі змістом заняття і приєднатися до його обговорення. Аналіз такого обговорення може проілюструвати якість засвоєння студентами теоретичного матеріалу, здатність до відстоювання своєї думки тощо.

Серед нових освітніх технологій особливе місце займає тренінгова форма навчання, яка $є$ альтернативою лекційному навчанню та сприяє розкриттю особистісного потенціалу студента, забезпечує формування його необхідних якостей, умінь, навичок, компетентностей.

Особливість педагогічного тренінгу полягає в орієнтуванні викладача ЗВО при його проведенні на принципи гуманізму, демократизму, студентоцентризму, реалізації інтерактивних методів навчання, створення комфортних умов для залучення до участі в ньому здобувачів вищої освіти. Тренінг у процесі навчання забезпечує індивідуальний підхід до отримання знань, набуття умінь і розвиток навичок , застосування їх на практиці тощо. Під час проведення тренінгів студенти засвоюють необхідний матеріал, занурюються у практичне розв'язання завдань, усвідомлюють необхідність свого подальшого розвитку і т. п.

Проте, визнане ефективним навчання шляхом проведення тренінгів схвалене не всіма викладачами. Для багатьох воно прийнятне на рівні задуму, оскільки не в усіх закладах вищої освіти є відповідно облаштовані аудиторії, наявні певні матеріальні ресурси тощо.

Серед популярних методів навчання останнім часом вирізняється метод коучингу. Він спрямований на активізацію процесів самонавчання та саморозвитку. Основою названого методу $€$ розвиток різностороннього мислення, орієнтування на налагодження зворотного зв'язку у процесі аналізу різних проблем тощо. Він $є$ різновидом інструментів розвитку soft skills (тренінги, які стосуються питань, пов'язаних із роботою в команді, управлінням часом, лідерством, особистим розвитком, проведенням презентацій і т. п.).

Набув поширення метод менторингу (англ. mentoring наставництво), яке полягає в передачі вмінь досвідченим наставником студенту. Наставляючи, тренер допомагає в індивідуальному, груповому чи колективному порядку розкрити потенціал кожного, знайти шлях досягнення поставленої мети.

Викладачі ЗВО для оволодіння інноваційними технологіями й методами навчання студентів мають стажуватись у європейських і світових закладах вищої освіти. Здобувачі вищої освіти теж повинні знаходити шляхи відвідувати закордонні ЗВО, вивчати у них окремі дисципліни, практикуватись тощо. Це сприятиме забезпеченню їхніх можливостей щодо самореалізації у прийдешньому. у "Положенні про порядок реалізації права на академічну мобільність Київського національного університету імені Тараса Шевченка" (2016) наголошено: "Академічна мобільність студентів Університету спрямована на підвищення якості вищої освіти, ефективності наукових досліджень і гармонізації стандартів вищої освіти, забезпечення конкурентоздатності випускників Університету на українському та міжнародному ринках освітніх послуг і праці, залучення зарубіжного інтелектуального потенціалу до роботи в Університеті, набуття студентами досвіду впровадження інших моделей створення та поширення знань й поглиблення інтеграційних процесів з питань навчання і наукових досліджень" [6, с. 3].

Стажування науково-педагогічних працівників 3 ВО за міжнародними програмами, які $\epsilon$ складовими процесу інтернаціоналізації вищої освіти, сприяє подоланню стереотипів щодо якості викладацької діяльності, спонукає до оволодіння іноземними мовами, допомагає в організації тісної взаємодії між закладами вищої освіти України та світу.

У країнах Європи викладачі та студенти ЗВО часто взаємодіють шляхом переходу від групових форм і методів навчання до індивідуально-групових: тьюторських занять, роботи в малих групах тощо. Вони віддають перевагу аналізу ситуацій, впровадженню проблемного та проєктного навчання, його нетрадиційним методам і формам.

Для викладача ЗВО велике значення має саморозвиток. Відомо, щоб якісно викладати - необхідно постійно змінюватись: проводити дослідження і використовувати здобуті результати як нову інформацію під час занять; цікавитись здобутками своїх колег і викладачів українських і іноземних університетів; обмінюватись досвідом із вітчизняними та зарубіжними колегами; вивчати різні документи; прослуховувати вебінари, онлайн-семінари тощо.

В "Етичному кодексі університетської спільноти КНУ імені Тараса Шевченка" вказано, що сучасні науково-педагогічні працівники мають "здобувати, примножувати, зберігати і поширювати наукові знання; розвивати й удосконалювати свою освітню майстерність; всебічно сприяти розвиткові та чистоті української мови, забезпечувати ії̈ функціонування в освітньому процесі, в науковій діяльності, в усіх сферах життя Університету; власним прикладом сприяти формуванню академічної культури 
студентів; сумлінно виконувати обов'язки викладача, науковця та наставника" [3, с. 1-2]. Саме від них залежить рівень навчальних досягнень і комунікативної культури випускників, розвиток їхнього критичного мислення, професійної компетентності.

Якість освітньої діяльності викладачів закладів вищої освіти має відповідно оцінюватись, щоб було зрозуміло, чия праця $\epsilon$ найбільш високо результативною. При цьому повинні враховуватись усі аспекти його профресійних досягнень: це рівень викладання читаних ним дисциплін і наслідки науково-дослідницької діяльності, навчально-методичної, виховної, громадської роботи, а також здатності налагоджувати міжнародні зв'язки для розширення можливостей своєї мобільності і студентів. Здійснюючи оцінку професійної діяльності викладача бажано аналізувати всі види його роботи у взаємозв'язку, зважаючи на специфіку функціонування конкретного ЗВО. Якісна складова діяльності викладача й рівень його компетентності залежить від багатьох фракторів, зокрема: його базової освіти, шляхів підвищення кваліфікації, участі в науковій діяльності університету, досвіду у певній галузі науки та практики, здатності встановлювати контакти з роботодавцями майбутніх випускників, доброчесності та критичному ставленні до корупції.

Важливо, щоб у кожному ЗВО діяла антикорупційна програма, яка "відображає підтримку Університетом і його керівництвом антикорупційної стратегії держави, що підтверджується використанням етичних стандартів і принципів надання публічної інформації про освітні послуги, встановлені розміри плати за ці послуги, наслідування кращих практик управління у сфері вищої освіти, підтримання ділової репутації Університету на високому рівні" [1, с. 3].

Висновки. Забезпечення закладами вищої освіти якості освітньої діяльності залежить від визначення ними відповідних принципів; здійснення моніторингу освітніх програм на предмет наявності у кожній з них необхідних ресурсів для навчання здобувачів вищої освіти, їхньої самостійної роботи з оприлюдненням цієї інформації; встановлення рейтингів навчальних, наукових та інших досягнень викладачів і розміщення даних на офіційному веб-сайті; проведення підвищення кваліфікації науково-педагогічних працівників в українських і зарубі- жних університетах; створення ефективної системи виявлення академічного плагіату в наукових працях представників академічної спільноти тощо. Освітня сфера, яка змінюється, відіграє важливу роль у формуванні світогляду молодих людей, їхнього духовного та професійного збагачення. Вона має зберегти кращі вітчизняні надбання та втілювати в практику актуальні ідеї забезпечення якості вищої освіти задля підготовки конкурентоспроможних фахівців.

Список використаних джерел

1. Антикорупційна програма Київського національного університету імені Тараса Шевченка. Затверджено Ректором 25.05.2015 р. http://www.univ.kiev.ua/pdfs/official/preventingcorruption/antykoruptsiyna prohrama.

2. Бугров В. Забезпечення якості вищої освіти: досвід Київського національного університету імені Тараса Шевченка. [Електронний ресурс]. Режим доступу: http://www.ihed.org.ua/images/pdf/rectors bugrov. pdf

3. Етичний кодекс університетської спільноти, ухвалений на конференції трудового колективу, протокол № 2 від 27.12.2017. http://www.univ.kiev.ua/pdfs/official/ethical-code/Ethical-code-of-the-university-community

4. Закон України "Про вищу освіту" від 01.07.2014 № 1556-VII https://zakon.rada.gov.ua/laws/show/1556-18

5. Закон України "Про освіту" від 05.09.2017 № 2145-VIII https://zakon.rada.gov.ua/laws/show/2145-19

6. Положення про порядок реалізації права на академічну мобільність студентів Київського національного університету імені Тараса Шевченка від 29. 06. 2016 p. http://mobility.univ.kiev.ua/wp-content/uploads/2016/08/.

\section{References}

1. Antykoruptsiyna prohrama Kyyivs'koho natsional'noho universytetu imeni Tarasa Shevchenka. Zatverdzheno Rektorom 25.05.2015 r. http://www.univ.kiev.ua/pdfs/official/preventingcorruption/antykoruptsiyna prohrama.

2. Buhrov V. Zabezpechennya yakosti vyshchoyi osvity: dosvid Kyyivs'koho natsional'noho universytetu imeni Tarasa Shevchenka. [Elektronnyy resurs]. Rezhym dostupu: http://www.ihed.org.ua/images/pdf/rectors bugrov. pdf

3. Etychnyy kodeks universytet·s'koyi spil'noty, ukhvalenyy na konferentsiyi trudovoho kolektyvu, protokol № 2 vid 27. 12. $2017 \mathrm{r}$. http://www.univ.kiev.ua/pdfs/official/ethical-code/Ethical-code-of-the-university-community. 12s

4.Zakon Ukrayiny "Pro vyshchu osvitu" vid 01.07.2014 № 1556-VII https://zakon rada gov ua/laws/show/1556-18

5. Zakon Ukrayiny "Pro osvitu" vid 05.09.2017 № 2145-VIII https://zakon.rada.gov.ua/laws/show/2145-19

6. Polozhennya pro poryadok realizatsiyi prava na akademichnu mobil'nist' studentiv Kyyivs'koho natsional'noho universytetu imeni Tarasa Shevchenka vid 29.06.2016 r. http://mobility.univ.kiev.ua/wp-content/uploads/2016/08/. 11s.

надійшла до редколегії 22.01.20

A. Marushkevych, Doktor of Pedagogical Sciences, Professor

Taras Shevchenko National University of Kyiv, Kyiv, Ukraine

\section{ENSURING THE QUALITY OF EDUCATION IN THE MODERN INSTITUTION OF HIGHER EDUCATION: CURRENT IDEAS}

The article considers current ideas for ensuring the quality of education in higher education institutions of Ukraine. Emphasis is placed on its essential characteristics: dynamism, internationality, student-centeredness and the importance for the modern teacher of regular professional development, internships in European and world higher education institutions to master innovative technologies and methods of teaching students. The importance of mutual coordination of curricula in domestic and foreign free economic zones in order to ensure the academic mobility of students has been explained. It is noted about the expansion of access to education in free economic zones not only for citizens of Ukraine, but also for representatives of other countries, their equality in terms of admission. The essence of the concepts "quality of educational activity", "quality of higher education", "academic community", "university community", "anti-corruption program" and the importance of research aspect of free economic activity, the importance of forming students' critical thinking skills are substantiated. The importance of interaction between teachers and students in the learning process, conducting interactive discussions, Internet forums, e-mail correspondence, contact in "chats", the use of tools for the development of soft skills (training on issues related to teamwork, time management, leadership, personal development, presentations, etc.). Attention is focused on the introduction of innovations in the educational process, taking into account the attitude of the whole team of research and teaching staff, the presence in the HEl equipped at the modern level of the auditorium, the necessary devices, technical tools.

The importance of having a personal cabinet for a modern teacher and student is briefly covered. Emphasis is placed on the importance of assessing the quality of teachers' educational activities. The necessity of functioning of the anti-corruption program in each free economic zone has been pointed out.

Keywords: quality of educational activity, quality of higher education, competencies, university community, academic community, teachers, students. 